\title{
Design of Microelementosis Correctors Based on Plant Source of Biologically Active Substances
}

\author{
Rodionova N.S. Popov E.S.* Klimova E.A. Pozhidaeva E.A. Mashneva A.V. \\ Boldyreva E.S.
}

Voronezh State University of Engineering Technologies, 19 Revolutsii ave., Voronezh, 394000, Russia

*Corresponding author. Email: e_s_popov@mail.ru

\begin{abstract}
This study aimed at investigating the possibility of solving the problem of microelementosis in the diet of various population groups by using available plant sources. The only way to correct microelementosis is to organize the intake of essential elements in the form of artificially synthesized forms or dietary intake. One of the most actual and promising means for correction of microelementosis could be freshly squeezed juices from fruits and vegetables and their blends. The mineral composition of freshly squeezed juices from plant raw materials were analyzed, as well as the possibility of providing the organism's need with a wide range of macro- and microelements has been determined. The methodology and the program product were developed on the basis of the received data bank which allows to design recipes of mixtures of the tested juices that ensure maximum digestion of mineral elements by the organism, taking into account possible antagonistic interactions.
\end{abstract}

\section{Keywords: microelementosis, plant sources, biologically active substances}

\section{INTRODUCTION}

Health deterioration of Russian population is increasing due to the negative effect of the environmental situation, social and economic factors that have a stressful effect on the body. Chronic diseases, an increase in the mortality of the able-bodied population, a decrease in the birth rate have been observed. In addition, the development of intensive agrotechnologies and logistics on the global scale leads to changes in the composition of all parts of cultivated plants, including not only fruits, but also the green part [1]. As a result, the content of biologically active compounds, macro- and microelements in food intake of farm animals and humans is reduced. Essential substances have the great importance in coverage of healthy state of all physiological systems of the body, and include microelements that act as active centers in the composition of more than two thousand enzymes, that ensure the catalysis of thousands of metabolic reactions in the body. The lack of mineral elements in the human diet leads to dyscrasia, or microelementosis. The degree of development of dyscrasia, or microelementosis depends on the volume of the deficit and the duration of its effect on the body [2]. Deficiency of mineral elements underlies the emergence of various pathological conditions, up to a lethal outcome. For example, lung cancer and stomach cancer are known to be more common among residents of territories where soil is depleted in iron, zinc, cobalt, and selenium [10]. The correlation between the content of nickel, titanium, strontium, chromium in the soil and coronary heart disease is known [3]. The concentration of various elements in the human body, that is necessary to supply its normal homeostasis, is different. Carbon, oxygen, hydrogen, nitrogen are in the largest quantities, then sulfur, phosphorus, calcium, sodium, magnesium, potassium and chlorine should be specified. Trace elements, such as copper, iodine, fluoride, arsenic, selenium, bromine and others are required in much smaller quantities. However, a lot of information about the need for so-called ultramicroelements, such as gold, mercury, thorium has been demonstrated recently [2].The necessity of presence in the organism of this or that element in microquantities is not the evidence of its lack of significance. For example, iodine deficiency can lead to endemic iodine deficiency cretinism, endemic goiter, functional cardiopathy. Magnesium deficiency is presented in increased activity of tendon reflexes, tremor, ataxia, heart rhythm disturbances. The lack of magnesium leads to children' behavioral disorders, impulsivity, attention deficit disorder. Stressful situations are also known to lead to an increase in magnesium waste with urine, in a way that facilitates the release of adrenaline and cortisone. Copper deficiency leads to dystrophic changes in the myocardium, dysmorphology of vessels, cartilage structure, hypodermic gonads, psychoemotional disorders [4]. The only way to correct microelementosis is to organize the intake of essential elements into the body in the form of artificially synthesized forms or with food [5]. It is known that the forms of intaking of microelements in the body vary significantly by the range of corrective effectiveness. The least effective form of microelementosis 
correctors is mineral salts. A more acceptable form is complex compounds of mineral elements and organic molecules - ligands. One of the latest and forward-looking means for correction of microelementosis are fresh fruit juices from fruits and vegetables and their blends as they do not contain coarse particles, do not require thorough rechewing, do not have a traumatic effect on gastrointestinal walls, which is especially important in ulcerative or erosive conditions of the mucosa. The present work attempts to determine the macro- and microelement composition of freshly squeezed juices from available domestic raw materials: spinach, celery stalk and celeriac, cherry, cranberries, green and red grapes, haw berry, and to investigate the blended systems of direct effective biocorrecting action on their basis.

\section{MATERIALS AND METHODS}

Freshly squeezed juices were obtained from fruits and vegetables grown in Voronezh region using the screw type juice extractor JMP 600. The mineral composition was determined by the mass-spectrographic method with inductively coupled plasma using quadrupole massspectrometer Nexion 300D (Perkin Elmer, USA).

\section{RESULTS}

The highest content of calcium was found in celeriac juice and haw berry juice $-436.0 \pm 44.0 \mu \mathrm{g} / \mathrm{g}$ and $644 \pm 64$ $\mu \mathrm{g} / \mathrm{g}$, respectively, the highest content of phosphorus in celeriac juice was also noted $-702.0 \pm 70.0 \mu \mathrm{g} / \mathrm{g}$, the highest content of potassium $-4070.0 \pm 41.0 \mu \mathrm{g} / \mathrm{g}$ and magnesium $-383.0 \pm 38.0 \mu \mathrm{g} / \mathrm{g}$ appeared in spinach juice. The highest sodium content was found in spinach, celeriac juice and celery stalk juice $-356.0 \pm 36.0 \mu \mathrm{g} / \mathrm{g}, 546.0 \pm$ $55.0 \mu \mathrm{g} / \mathrm{g}$ and $967.0 \pm 97.0 \mu \mathrm{g} / \mathrm{g}$, respectively. The macronutrient composition of the studied freshly squeezed juices was determined (Figure 1, Table 1).

The content determination of vitally important microelements in the analyzed juices showed that celery stalk juice is the most significant source of copper, iron and zinc, the number of these elements is $1.34 \pm 0.13 \mu \mathrm{g} / \mathrm{g}$, $10.44 \pm 1.04 \mu \mathrm{g} / \mathrm{g}, 3,21 \pm 0.32 \mu \mathrm{g} / \mathrm{g}$, respectively. Grape varieties "Lancelot" (green grape) and "Everest" (red grape), grown in the Voronezh region, contain $0.50 \pm 0.06$ $\mu \mathrm{g} / \mathrm{g}$ and $0.90 \pm 0.109 \mu \mathrm{g} / \mathrm{g}$ of iodine. The results of the determination of microelements and the ratio of Daily Value are described in Figure 2 and in Table 2.

Quantity determination of conditionally vital elements showed that the grape juice of "Lancelot" (green grape) and "Everest" (red grape) varieties contains the most significant quantities of boron $-3.52 \pm 0.35 \mu \mathrm{g} / \mathrm{g}$ and 3.23 $\pm 0,32 \mu \mathrm{g} / \mathrm{g}$, respectively, while the celeriac juice contains the largest amounts of nickel, vanadium, arsenic $-0.14 \pm$ $0.017 \mu \mathrm{g} / \mathrm{g}, 0.01 \pm 0.002 \mu \mathrm{g} / \mathrm{g}$, and $0.016 \pm 0.002 \mu \mathrm{g} / \mathrm{g}$, respectively. Berry juice contains a significant amount of vanadium $-0,006 \pm 0,0013 \mu \mathrm{g} / \mathrm{g}$. Cranberry juice appeared to be a source of lithium, it contains $0.013 \pm 0.002 \mu \mathrm{g} / \mathrm{g}$. The results of the determination of conditionally vital elements content in the studied juices are shown in Figure 3. Daily Value of the examined conditionally vital elements in accordance with the recommendations of Skalniy A $[6,7]$ is reported in Table 3.

Tables 1-3 and Figures $1-3$ demonstrated that the studied juices could provide the body's needs in a wide range of macro- and microelements. When composing beverages from freshly squeezed juices, it should be taken into account that some minerals could interfere the assimilation of others $[8,9]$. The analysis of conditionally toxic elements value in freshly squeezed juices showed their insignificant amounts that are not exceeding the average daily intake rate when consuming up to 1000 $\mathrm{g} /$ day of the tested products (Table 4).

Table 1 Daily value (\%) of macronutrients when $100 \mathrm{~g}$ of freshly squeezed juices are consumed

\begin{tabular}{|c|c|c|c|c|c|c|c|c|c|}
\hline $\begin{array}{c}\text { Chemical } \\
\text { name }\end{array}$ & $\begin{array}{c}\text { Celeriac } \\
\text { juice }\end{array}$ & $\begin{array}{c}\text { Celery } \\
\text { stalk } \\
\text { juice }\end{array}$ & $\begin{array}{c}\text { Cherry } \\
\text { juice }\end{array}$ & $\begin{array}{c}\text { Cranberry } \\
\text { juice }\end{array}$ & $\begin{array}{c}\text { Black } \\
\text { currant } \\
\text { juice }\end{array}$ & $\begin{array}{c}\text { Spinach } \\
\text { juice }\end{array}$ & $\begin{array}{c}\text { Green } \\
\text { grape } \\
\text { juice }\end{array}$ & $\begin{array}{c}\text { Red } \\
\text { grape } \\
\text { juice }\end{array}$ & $\begin{array}{c}\text { Haw } \\
\text { berry } \\
\text { juice }\end{array}$ \\
\hline $\mathrm{Ca}$ & 4.0 & 2.70 & 1.20 & 0.61 & 2.42 & 0.04 & 1.01 & 1.03 & 6.4 \\
\hline $\mathrm{K}$ & 11.41 & 8.94 & 7.32 & 3.06 & 7.98 & 16.0 & 9.56 & 5.16 & 9.75 \\
\hline $\mathrm{Mg}$ & 4.57 & 2.37 & 3.27 & 1.35 & 2.70 & 10.0 & 2.04 & 1.85 & 4.32 \\
\hline $\mathrm{Na}$ & 4.20 & 7.40 & 0.09 & 0.29 & 0.10 & 2.70 & 0.14 & 0.09 & 0.06 \\
\hline $\mathrm{P}$ & 5.40 & 1.92 & 2.58 & 0.66 & 3.73 & 2.23 & 3.20 & 2.22 & 1.38 \\
\hline
\end{tabular}




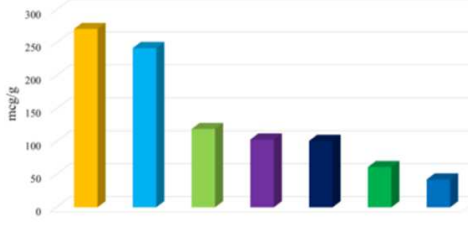

$\mathrm{Ca}$

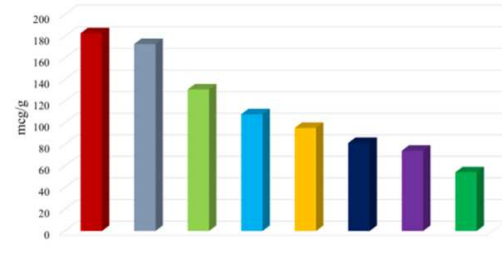

$\mathrm{Mg}$

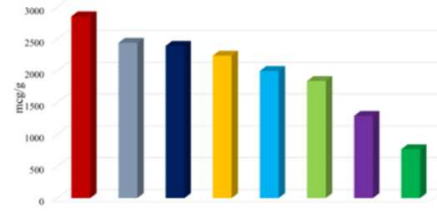

K

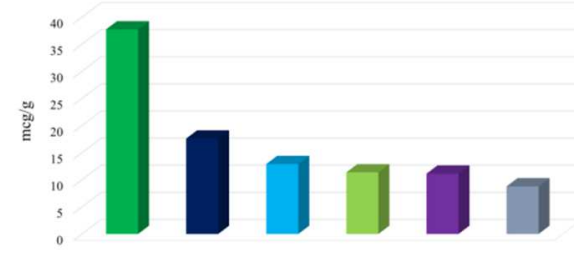

$\mathrm{Na}$

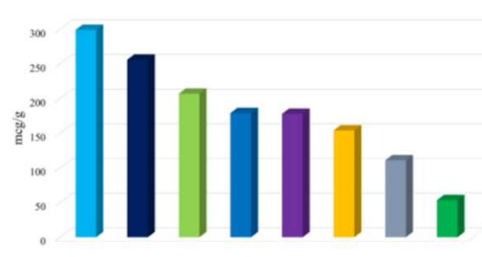

$P$

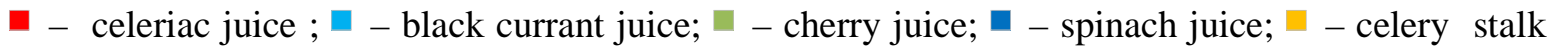
juice; - cranberry juice; - green grape juice; - red grape juice; - naw berry juice

Figure 1 The value of macronutrients $(\mu \mathrm{g} / \mathrm{g})$ in freshly squeezed juices.

Table 2 Daily value (\%) of macronutrients in $100 \mathrm{~g}$ of freshly squeezed juices

\begin{tabular}{|c|c|c|c|c|c|c|c|c|c|}
\hline $\begin{array}{c}\text { Chemical } \\
\text { name }\end{array}$ & $\begin{array}{c}\text { Celeriac } \\
\text { juice }\end{array}$ & $\begin{array}{c}\text { Celery } \\
\text { stalk } \\
\text { juice }\end{array}$ & $\begin{array}{c}\text { Cherry } \\
\text { juice }\end{array}$ & $\begin{array}{c}\text { Cranberry } \\
\text { juice }\end{array}$ & $\begin{array}{c}\text { Black } \\
\text { currant } \\
\text { juice }\end{array}$ & $\begin{array}{c}\text { Spinach } \\
\text { juice }\end{array}$ & $\begin{array}{c}\text { Green } \\
\text { grape } \\
\text { juice }\end{array}$ & $\begin{array}{c}\text { Red } \\
\text { grape } \\
\text { juice }\end{array}$ & $\begin{array}{c}\text { Haw } \\
\text { berry } \\
\text { juice }\end{array}$ \\
\hline $\mathrm{Co}$ & 5.0 & 2.30 & 3.0 & 2.30 & 4.30 & 2.90 & 1.0 & 1.0 & 9.0 \\
\hline $\mathrm{Cr}$ & 10.20 & 7.40 & 8.0 & 6.0 & 7.60 & 7.20 & 10.0 & 4.0 & 8.0 \\
\hline $\mathrm{Cu}$ & 13.40 & 2.21 & 6.03 & 1.83 & 4.18 & 7.98 & 8.30 & 6.10 & 3.10 \\
\hline $\mathrm{Fe}$ & 10.44 & 0.12 & 0.13 & 0.26 & 0.32 & 0.25 & 0.54 & 0.27 & 6.75 \\
\hline $\mathrm{I}$ & 1.33 & 1.60 & 0.60 & 0.66 & 0.80 & 4.20 & 33.33 & 60.0 & 28.0 \\
\hline $\mathrm{Mn}$ & 7.0 & 3.50 & 6.50 & 7.95 & 8.15 & 6.25 & 1.90 & 1.25 & 8.55 \\
\hline $\mathrm{Se}$ & 3.85 & 1.85 & 0.57 & 0.55 & 1.30 & 2.28 & 2.85 & 4.28 & 0.55 \\
\hline $\mathrm{Zn}$ & 2.67 & 0.80 & 1.62 & 0.63 & 1.15 & 1.50 & 1.05 & 0.71 & 2.95 \\
\hline
\end{tabular}




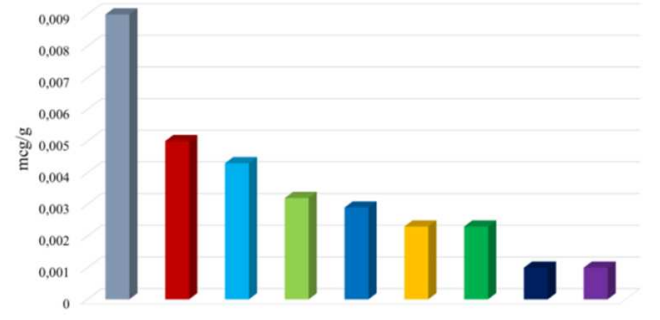

Co

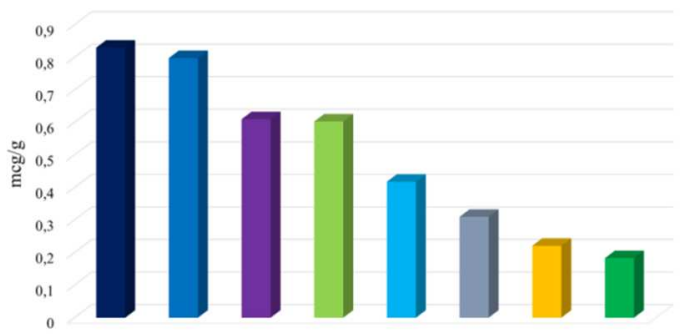

$\mathrm{Cu}$

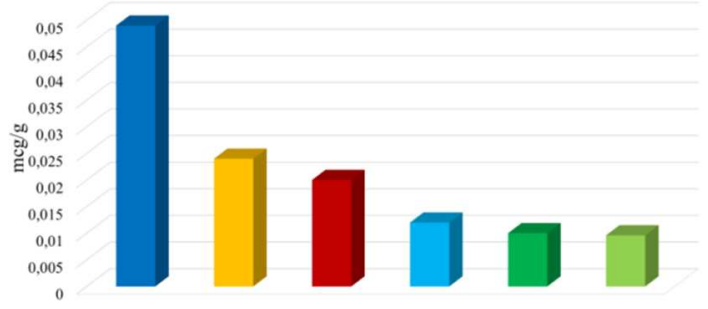

।

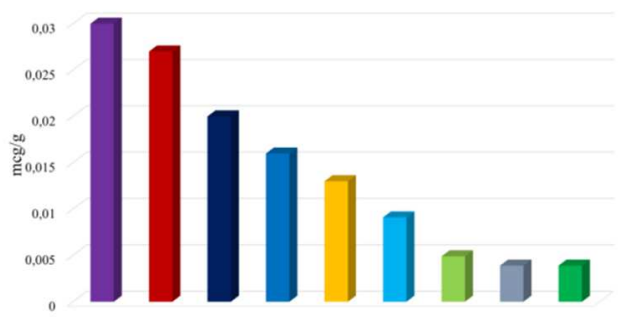

$\mathrm{Se}$
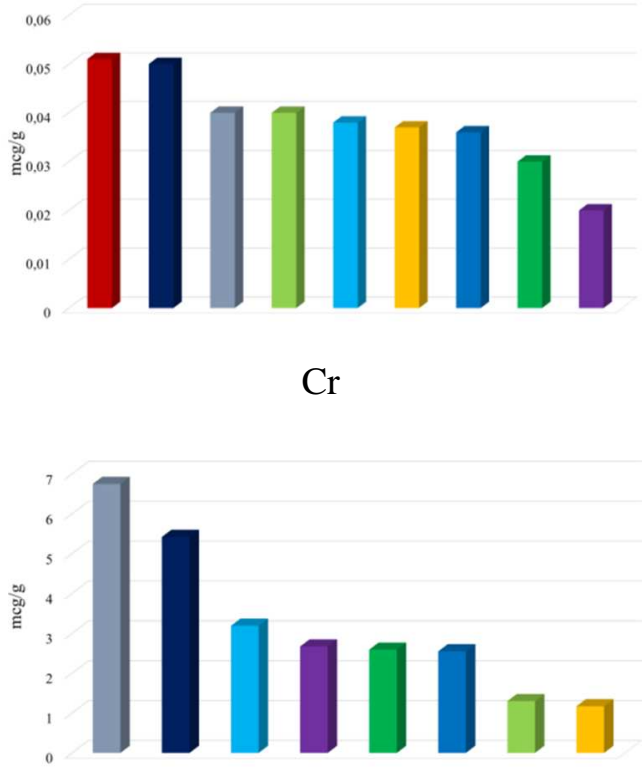

$\mathrm{Fe}$

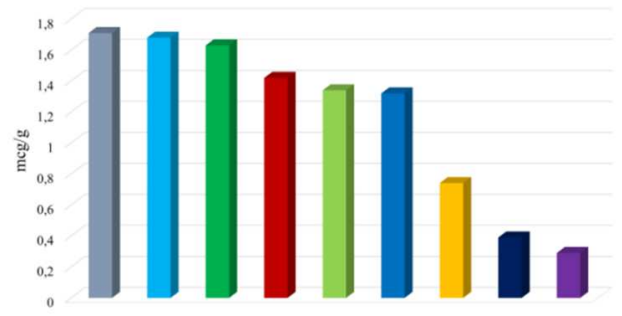

$\mathrm{Mn}$

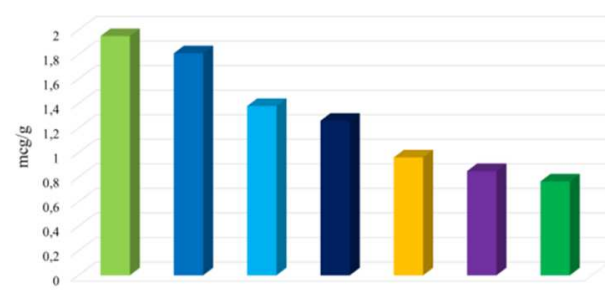

$\mathrm{Zn}$

- - celeriac juice ; - - black currant juice; - - cherry juice; - - spinach juice;

$\square$ - celery stalk juice; $\square$ - cranberry juice; $\square$ - green grape juice; $\square$ - red grape juice;

- haw berry juice

Figure 2 The value of vital microelements $(\mu \mathrm{g} / \mathrm{g})$ in freshly squeezed juices. 


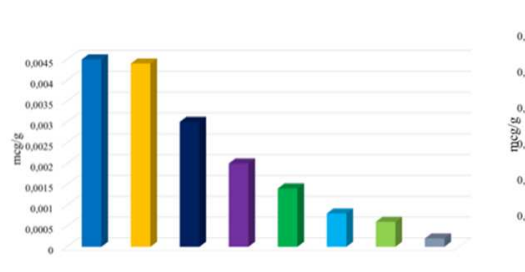

As

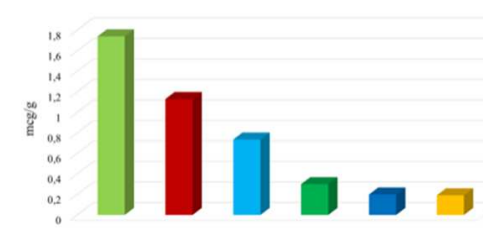

B

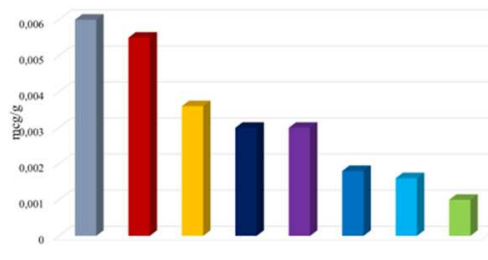

$\mathrm{Li}$

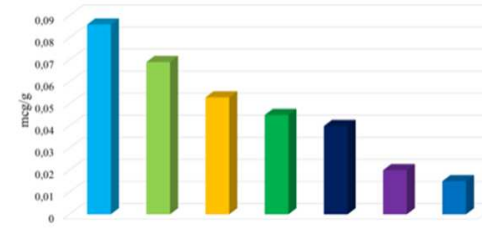

$\mathrm{Ni}$

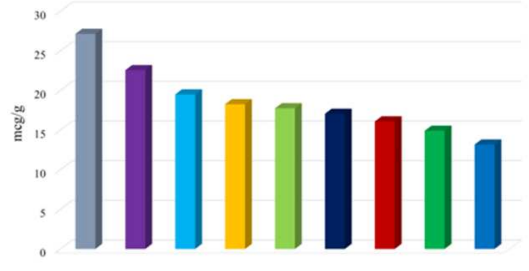

$\mathrm{Si}$

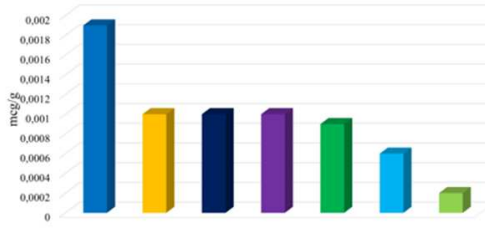

$\mathrm{V}$

- celeriac juice; - black currant juice; - - cherry juice; - - spinach juice; $\quad$ - celery stalk juice;

- - cranberry juice; - green grape juice; - red grape juice; - naw berry juice

Figure 3 The value of conditionally vital microelements $(\mu \mathrm{g} / \mathrm{g})$ in freshly squeezed juices.

Table 3 Daily value (\%) of condition vital macronutrients in $100 \mathrm{~g}$ of freshly squeezed juices

\begin{tabular}{|c|c|c|c|c|c|c|c|c|c|}
\hline $\begin{array}{c}\text { Chemical } \\
\text { name }\end{array}$ & $\begin{array}{c}\text { Celeriac } \\
\text { juice }\end{array}$ & $\begin{array}{c}\text { Celery } \\
\text { stalk } \\
\text { juice }\end{array}$ & $\begin{array}{c}\text { Cherry } \\
\text { juice }\end{array}$ & $\begin{array}{c}\text { Cranberry } \\
\text { juice }\end{array}$ & $\begin{array}{c}\text { Black } \\
\text { currant } \\
\text { juice }\end{array}$ & $\begin{array}{c}\text { Spinach } \\
\text { juice }\end{array}$ & $\begin{array}{c}\text { Green } \\
\text { grape } \\
\text { juice }\end{array}$ & $\begin{array}{c}\text { Red } \\
\text { grape } \\
\text { juice }\end{array}$ & $\begin{array}{c}\text { Haw } \\
\text { berry } \\
\text { juice }\end{array}$ \\
\hline $\mathrm{As}$ & 0.80 & 0.005 & 0.08 & 0.18 & 0.10 & 0.60 & 0.40 & 0.26 & 0.26 \\
\hline $\mathrm{B}$ & 7.53 & 1.26 & 11.6 & 20.0 & 4.90 & 1.26 & 23.46 & 21.53 & 20.6 \\
\hline $\mathrm{Li}$ & 0.47 & 0.21 & 0.05 & 0.76 & 0.09 & 0.10 & 0.17 & 0.17 & 0.35 \\
\hline $\mathrm{Ni}$ & 9.33 & 3.53 & 4.60 & 3.0 & 5.73 & 1.0 & 2.66 & 1.33 & 11.3 \\
\hline $\mathrm{Si}$ & 5.36 & 6.10 & 5.92 & 4.97 & 6.50 & 4.40 & 5.68 & 7.52 & 9.04 \\
\hline $\mathrm{V}$ & 4.50 & 0.5 & 0.10 & 0.45 & 0.30 & 0.95 & 0.50 & 0.50 & 3.0 \\
\hline
\end{tabular}

Table 4 The value of condition toxic elements in freshly squeezed juices

\begin{tabular}{|l|l|l|l|l|l|l|l|l|l|}
\hline Al & $3.15 \pm 0.32$ & $0.55 \pm 0.064$ & $0.31 \pm 0.042$ & $0.033 \pm 0.045$ & $0.54 \pm 0.063$ & $0.51 \pm 0.059$ & $0.55 \pm 0.066$ & $0.81 \pm 0.097$ & $2.1 \pm 0.21$ \\
\hline $\mathrm{Cd}$ & $0.047 \pm 0.007$ & $0.0032 \pm 0.00063$ & $<0.0005$ & $\begin{array}{l}0.0039 \pm \\
0.00078\end{array}$ & $\begin{array}{l}0.0019 \pm \\
0.00038\end{array}$ & $0.033 \pm 0.005$ & $0.00048 \pm .0001$ & $0.0006 \pm 0.00018$ & $0.01 \pm 0.0019$ \\
\hline $\mathrm{Hg}$ & $<0.0036$ & $<0.0036$ & $<0.0036$ & $<0.0036$ & $<0.0036$ & $<0.0036$ & $0.0036 \pm 0.0007$ & $<0.0036$ & $<0.0036$ \\
\hline $\mathrm{Pb}$ & $0.015 \pm 0.002$ & $0.0097 \pm 0.00194$ & $0.0048 \pm 0.00095$ & $0.0026 \pm$ & $0.0052 \pm$ & $0.0053 \pm 0.00107$ & $0.007 \pm 0.0015$ & $0.007 \pm 0.0014$ & $0.02 \pm 0.002$ \\
\hline $\mathrm{Sn}$ & $0.0087 \pm 0.0018$ & $0.009 \pm 0.0019$ & $0.0084 \pm 0.0017$ & - & 0.00052 & 0.00104 & & & \\
\hline $\mathrm{Sn}$ & $0.0087 \pm 0.0018$ & $0.009 \pm 0.0019$ & $0.0084 \pm 0.0017$ & - & $0.003 \pm 0.005$ & $0.0043 \pm 0.009$ & $0.03 \pm 0.005$ & $0.005 \pm 0.0011$ & $0.003 \pm 0.0006$ \\
\hline $\mathrm{Sr}$ & $0.85 \pm 0.0097$ & $0.73 \pm 0.0079$ & $0.19 \pm 0.024$ & $0.17 \pm 0.019$ & $0.78 \pm 0.0085$ & $0.06 \pm 0.0023$ & $0.45 \pm 0.054$ & $0.44 \pm 0.053$ & - \\
\hline
\end{tabular}

The fundamental feature of the functioning of minerals in the body is their interaction with each other, which is often evident as a form of antagonistic effects, manifested in auto-inhibition of intrinsic absorption in the digestive 
tract or in the opposite effect on biochemical functions in the body.

The aim of the present study was to develop the methodology for blending freshly squeezed juices with a predictably set ratio of minerals that provide their maximum absorption by the body. As a result of

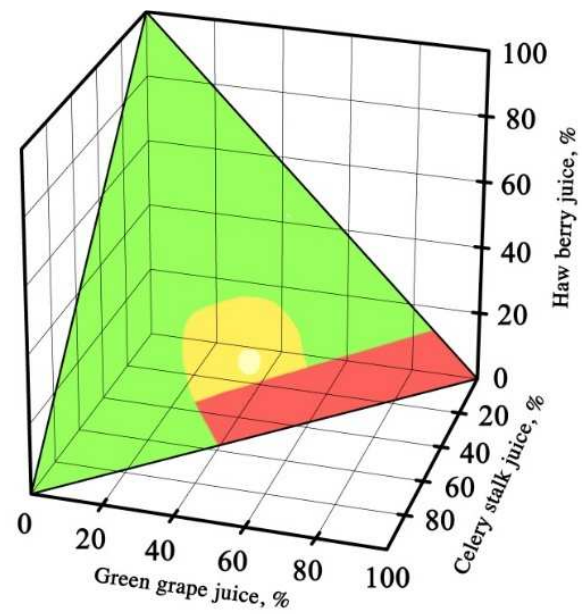

a

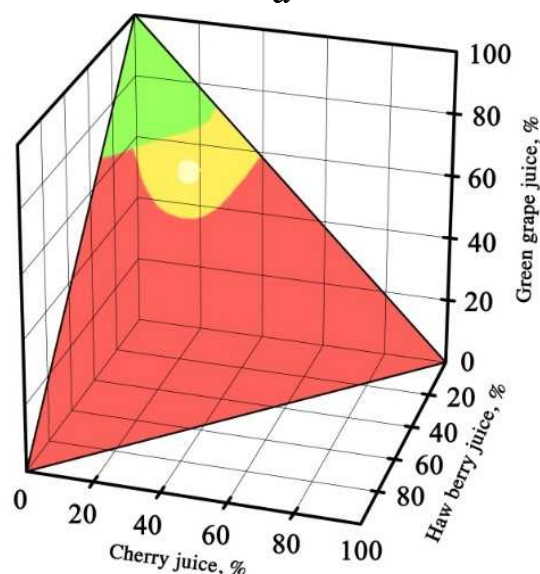

$\mathrm{c}$

( - optimal; - inhibitory; $\mathbf{\square}$ - auto-inhibitory) mathematical processing of the database of freshly squeezed juices mineral content, nomograms were developed for designing of blended systems based on the studied raw materials that minimize the antagonistic effect and provide the maximum digestibility of minerals by the body (Figure 4).

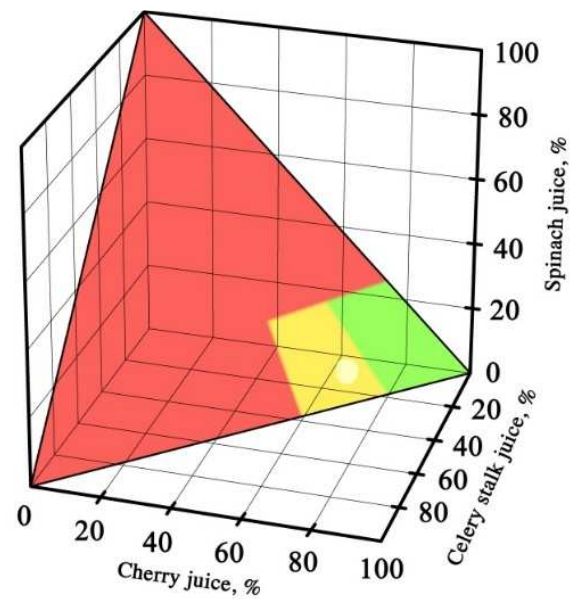

b

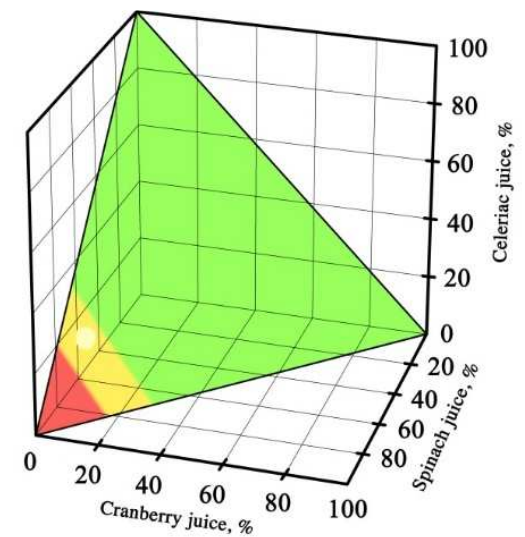

d

Figure 4 Nomogram for determining the optimum ratio of freshly squeezed juices in mixtures and providing optimal mineral/antagonist ratios: $\mathrm{a}-\mathrm{Ca} / \mathrm{P} ; \mathrm{b}-\mathrm{Zn} / \mathrm{Fe} ; \mathrm{c}-\mathrm{P} / \mathrm{Mg} ; \mathrm{d}-\mathrm{Mn} / \mathrm{I}$

The specially developed software (Ruby 2.2, Ruby on Rails 4.2) was used, which implements the object-oriented programming method. The criterion of defining optimum was to achieve the maximum content of $\mathrm{Ca}, \mathrm{Zn}, \mathrm{P}, \mathrm{Mn}$ in juice blendings, while providing the minimum amounts of the corresponding antagonistic competitors $-\mathrm{P}, \mathrm{Fe}, \mathrm{Mg}, \mathrm{I}$. The obtained nomograms (Figure 5) show the possibility of providing specified ratios of mineral elements in setting of blend of three-component mixtures from the studied juices. The area corresponding to the most optimal mineral/antagonist relationship is indicated in white. The zone of an acceptable optimal area is indicated by yellow color, while the green color corresponds to the minimum content of minerals-antagonists, the red color corresponds to their maximum content. The component's ratio in the mixtures is indicated in red and it does not promote the assimilation of $\mathrm{Ca}, \mathrm{Zn}, \mathrm{P}$ and $\mathrm{Mn}$.

The component composition of the juice blendings, which provide the maximum absorption of $\mathrm{Ca}, \mathrm{Zn}, \mathrm{P}, \mathrm{Mn}$, is described in Table 5 . 
Table 5 Examples of formulas for the composition of freshly squeezed juices blends to provide maximum assimilation of $\mathrm{Ca}, \mathrm{Zn}, \mathrm{P}, \mathrm{Mn} \%$

\begin{tabular}{|c|c|c|c|c|c|c|c|c|}
\hline $\begin{array}{c}\text { Correction } \\
\text { deficit }\end{array}$ & $\begin{array}{c}\text { Celeriac } \\
\text { juice }\end{array}$ & $\begin{array}{c}\text { Celery } \\
\text { stalk juice }\end{array}$ & $\begin{array}{c}\text { Cherry } \\
\text { juice }\end{array}$ & $\begin{array}{c}\text { Cranberry } \\
\text { juice }\end{array}$ & $\begin{array}{c}\text { Spinach } \\
\text { juice }\end{array}$ & $\begin{array}{c}\text { Green } \\
\text { grape } \\
\text { juice }\end{array}$ & $\begin{array}{c}\text { Haw } \\
\text { berry } \\
\text { juice }\end{array}$ & Total \\
\hline $\mathrm{Ca}$ & - & $37.0-37.9$ & - & - & - & $47.1-48.0$ & $16.0-16.9$ & - \\
\hline $\mathrm{Zn}$ & - & $26.1-27.0$ & $62.0-62.9$ & - & $12.0-12.9$ & - & -100 \\
\hline $\mathrm{P}$ & - & - & $27.0-27.9$ & - & - & $5.0-58.9$ & $15.1-16.0$ \\
\hline $\mathrm{Mn}$ & $34.0-34.9$ & & & $13.1-14.0$ & $53.0-53.9$ & & \\
\hline
\end{tabular}

\section{CONCLUSION}

The obtained experimental data on the value of mineral elements in freshly squeezed juices from celery stalk, celeriac, cherry, cranberry, black currant, spinach, green grape, red grape, haw berry were used as a database for the development of the software product that allows one to design formulas for juice mixtures. With the help of the developed software product it could be possible to design blends of freshly squeezed juices to provide the maximum absorption of mineral elements by the organism, taking into account possible antagonistic interactions of minerals that reduce the effectiveness of their biocorrecting effects.

\section{ACKNOWLEDGMENTS}

This work was supported by the Russian Science Foundation (agreement 19-76-10023).

\section{REFERENCES}

[1] E. Combet, C. Buckton, Micronutrient deficiencies, vitamin pills and nutritional supplements, Med. 47 (2019) 145

[2] M. Renate, K. Gellein, Minerals and trace elements in commercial infant food, Food and Chem. Toxicol. 46 (2008) 3339.

[3] S.T. Minzanova, V.F. Mironov, A.B. Vyshtakalyuk, Complexation of pectin with macro- and microelements. Antianemic activity of $\mathrm{Na}, \mathrm{Fe}$ and $\mathrm{Na}, \mathrm{Ca}, \mathrm{Fe}$ complexes, Carbohydrate Polymers 134 (2015) 524.

[4] T. Studzińskia, J. Matras, E.R.J. Grelab, Chapter 16 Minerals: functions, requirements, excessive intake and toxicity, Biol. of Growing Anim. 4 (2006) 467.

[5] A. Skalniy, Norms of physiological needs in food substances and energy for various groups of the population, Med. 5 (2008) 44.

[6] A. Skalniy, Microelementoses of man: hygienic diagnostics and correction, Microelem. in med. 1 (2000) 2.

[7] I. Radysh, A. Skalniy, Introduction to Medical Elementology, Moscow State Univer. Press, Moscow, 2015.

[8] E.S. Popov, N.S. Rodionova, O.A. Sokolova, N.Yu. Mazurenko, Evaluation of the prospects for the production of products from domestic plant materials balanced in polyunsaturated fatty acids, Hygiene and Sanitat. 95 (2016) 79.

[9] N.S. Rodionova, V.A. Isaev, A.B. Vishnyakov, E.S. Popov, Influence of oil and flour from wheat germ meal on the lipid metabolism of students and university professors, Nutrit. Issues 85 (2016) 57.

[10] M. Welna, A. Szymczycha-Madeja, P. Pohl, Selenium and Other Beneficial Elements in Fruit Juices, Fruit Juices 4 (2018) 75. 